\title{
Response of White Spruce Plantation to Three Levels of Thinning from Below 1958-1978
}

\author{
W. M. Stiell \\ Petawawa National Forestry Institute \\ Canadian Forestry Service \\ Chalk River, Ontario
}

\begin{abstract}
In 1958 a thinning experiment to examine the relation of stand growth of white spruce (Picea glauca (Moench) Voss) to density of residual growing stock was established at the Petawawa national Forestry Institute in a 33-year-old plantation growing on a sandy oldfield site. A treatment series consisted of sample plots thinned from below to basal area levels of $18.4,25.3$ and $32.1 \mathrm{~m}^{2} / \mathrm{ha}$, together with unthinned plots serving as controls. Two such replicates were established. The plots were remeasured and thinned again to the prescribed basal areas in 1968 and 1978. Diameter growth and form quotient were clearly related to degree of thinning. Volume growth was reduced at the lowest residual basal area. The untreated plots contained the highest volume in 1978 but mortality had reduced their total production of merchantable wood by about $10 \%$ compared with the thinnings plus standing crop of the two lighter treatments. Thinning to leave a basal area in the range of about 22 to $35 \mathrm{~m}^{2} /$ ha should yield 11 to $60 \mathrm{~m}^{3} / \mathrm{ha}$ of merchantable wood, depending on plantation age and intensity of cut, without reducing stand growth.
\end{abstract}

\section{Résumé}

Une expérience d'éclaircie a été entreprise en 1958, à l'Institut forestier national de Petawawa, dans une plantation d'épinette blanche (Picea glauca (Moench) Voss) âgée de 33 ans poussant dans un champ sableux, pour établir la relation entre la croissance du peuplement et la densité du matériel sur pied résiduel. L'expérience a porté sur des placettes d'échantillonnage éclaircies par le bas pour obtenir des surfaces terrières de $18.4,25.3$ et 32.1 $\mathrm{m}^{2} /$ ha à côté desquelles avaient été déterminées des parcelles témoins. Deux ensembles ont été étudiés. Les parcelles ont été remesurées et éclaircies de nouveau, selon les mêmes valeurs, en 1968 et 1978. L'accroissement en diamètre et le coefficient de décroissance étaient fonction directe de l'éclaircie. La croissance volumétrique était moindre dans le cas de la plus petite surface terrière résiduelle. En 1978, le volume était le plus grand dans les parcelles non traitées, mais la mortalité y avait fait baisser la production globale de bois marchand de $10 \%$, environ, par rapport aux produits d'éclaircie et au matériel sur pied aux deux endroits où le traitement avait été le moins important. Les activités d'éclaircie menées de façon à laisser une surface terrière de 22 à $35 \mathrm{~m}^{2} / \mathrm{ha}$ devraient produire de 11 à $60 \mathrm{~m}^{3} / \mathrm{ha}$ de bois marchand, selon l'âge de la plantation et l'intensité relative de la coupe, sans nuire à la croissance du peuplement.

\section{Introduction}

In 1958 a thinning experiment to examine the relation of stand growth of white spruce (Picea glauca (Moench) Voss) to density of the residual growing stock was established at the Petawawa National Forestry Institute in three plantations ca. 35 years old. The stands were measured and thinned again in 1968 and 1978. Results of the first 10 years were described by Stiell (1970), and this report deals with both decades. The study was part of a program aimed at evaluating alternative methods of managing white spruce plantations, including various thinning methods as well as clear cutting without intermediate treatments.

Starting in 1970, and lasting for several years, an infestation of spruce budworm (Choristoneura fumiferana Clem.) caused serious damage and mortality to spruce and balsam fir (Abies balsamea (L.) Mill.) in the Institute forest. Despite a program of chemical spraying aimed at protecting research areas, some plantations, including part of the thinning experiment, did not escape severe attack by the budworm. In consequence, the 1978 analysis of results was confined to one stand (Plantation 12), and the 1958-68 data were recompiled using only the plots in that plantation.

\section{Methods and Materials}

\section{Design}

Rationale and methodology of this experiment were previously set forth (Stiell 1970) and will not be repeated in detail. The design involves thinning from below to reduce stands to fixed basal areas $\left(18.4,25.3\right.$ and $\left.32.1 \mathrm{~m}^{2} / \mathrm{ha}\right)$, and keeping an area unthinned to serve as a control. A replicate, then, consisted of the four treatments, each sampled by a 0.8 -ha permanent plot. Two such replicates were located in Plantation 12.

\section{Plantation History and Conditions in 1958}

The plantation was established on an old field site, with soil of fresh, windblown, loamy and fine sand over compact fine and medium sand. Planting was in ploughed furrows at a spacing of ca. $1.6 \times 1.6 \mathrm{~m}$. Survival at the time of first treatment in 1958 averaged $86 \%$. The plantation was then 33 years from planting and had an average dominant height of $12.8 \mathrm{~m}$, equivalent to site Index Class $18 \mathrm{~m}$ at age 50 (Berry 1978). Crowns had long since closed and branches were dead to heights of ca. 4 to $6 \mathrm{~m}$. Light values at ground level were only about $2-1 / 2 \%$ of full sunlight. Few volunteer stems were present, and ground cover was virtually confined to mosses, present on about $40 \%$ of the area; the commonest species were Brachythecium rutabulum (Hedw.) BSC and Pleurozium schreberi (Brid.) Mitt. About $5 \%$ of the spruce were afflicted by a stem canker (Cytospora kunzei Sacc.).

\section{Measurement and Compllation}

Procedures previously reported were repeated in 1978. Diameters of all trees were taken at breast height, and at half height above b.h. on 5 trees per one-inch diameter class to allow calculation of form quotient. Total height and height to the base of the live crown were taken on 10 trees in each diameter class. Basal area, volume (from Form-class Volume Tables [Anon. 1948]) and foliage weights were compiled, and stand tables were prepared for each plot and date, before and after thinning. In 1978 all values for that and previous measurements were converted to SI units;

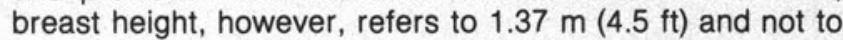
the metric standard of $1.30 \mathrm{~m}$. Subsidiary studies involved systematic sampling of ground cover and measurements in 1958 and 1968 of light intensity on the forest floor. 


\section{Analysis}

The criterion for plot acceptability with regard to budworm damage was the amount of 1968-78 mortality. Excessive numbers of trees dying on a plot compared with other plots in the same treatment, and with its own 1958-68 mortality, led to rejection of post -1968 results. Only one plot in Plantation 12 (at the $32.1 \mathrm{~m}^{2} / \mathrm{ha}$ level) was rejected in this way. For the analysis, data up to 1968 were accepted for this plot, but missing values for $1968-78$ were provided for it by applying the procedure appropriate to a randomized block design (Freese 1967).

Growth for each 10-year period was analyzed separately, using ANOVA for the above design. F-tests were made of significance of treatment effects; of linear and quadratic trends of treatments; of growth at $18.4 \mathrm{~m}^{2} / \mathrm{ha}$ vs. the other treatments; and controls vs. the other treatments.

\section{Thinning}

Marking designated mainly the smaller trees for removal, together with damaged and cankered individuals, halves of "doubles" and volunteers - concessions to uniform spacing in the residual stand were made in 1958 and 1968, but not in 1978. Surrounds were marked similarly to the plots.

In 1958 stand density demanded considerable care to avoid damage by partial cutting. Felled trees were bucked in situ and man-handled off the plots. Every fifth row was removed between treatment areas providing permanent extraction routes, and the intervening rows were also thinned. In 1968 most material was removed as tree lengths by a wheeled skidder brought to the edge of the plots, and in 1978 the skidder entered the plots (Fig. 1). Slash was lopped and scattered at each thinning.

\section{Results}

\section{Stand Conditions}

The quantity of light near the forest floor was found to be consistently associated with stand basal area. Changes in amount of light over a period of time were related both to basal area growth in that time and to the basal area at the beginning of the period. Thus in 1958 after-thinning values ranged from the $2-1 / 2 \%$ of full light on the controls to $24 \%$ at $18.4 \mathrm{~m}^{2} / \mathrm{ha}$. In 1968 before thinning these limits were $1-1 / 2 \%$ and $7 \%$ respectively. After thinning in 1968 the maximum was raised to over $20 \%{ }^{1}$

In 1968 the amount of ground cover on the treated plots had increased considerably, and roughly in proportion to degree of thinning, although featuring mainly the same moss species. By 1978 the thinned plots still had an extensive moss cover, and in addition numerous tree seedlings ${ }^{2}$. The regeneration on plots of the two heaviest treatments was vigorous and up to $2 \mathrm{~m}$ tall; on the most lightly thinned areas few seedlings were considered to be established. On the other hand, the controls showed little alteration in species or abundance of ground cover from 1958 to 1978.

Despite removal of cankered trees in the first two thinnings, ca. $1 \%$ of all trees were found to be so affected in 1968 and $5 \%$ in 1978. Fruiting bodies of a root rot (Polyporus tomentosus Fr.) were found in the plantation but outside the experimental area in 1968, and on the margin of one of the plots in 1978 - several trees were probably affected. Changes in stand appearance are indicated in Fig. 2. 1Stiell, W. M. 1970. Changes in light conditions in thinned white spruce plantations.
Petawawa Forest Experiment Station Binder Report 595. 6 p. Unpubl.

${ }^{2}$ Chiefly white birch (Betula papyrifera Marsh.), sugar and red maple (Acer saccharum Marsh. and A. rubrum L.), beech (Fagus grandifolia Ehrh.), balsam fir (Abies balsamea [L.] Mill.) and white pine (Pinus strobus L.).

\section{Stand Development}

Selected parameters (each the mean of two plots values) for the various dates are shown in Tables 1 and 2 . They indicate development with time of the main stand attributes under the different treatments.

Mean $\mathrm{dbh}$ is immediately increased by a thinning from below, and the heavier the cut the greater the effect as clearly seen in the after-thinning values. Owing in part to this phenomenon greater $\mathrm{dbh}$ was strongly associated with degree of thinning. Related to this are diameter range and size limits (Table 3). By 1978 the controls not only had the smallest mean $\mathrm{dbh}$, but their maximum diameters were smaller than those on the two stands of lowest density; however size range on the controls was greatest owing to the retention of lower diameter classes. Mean height was in-

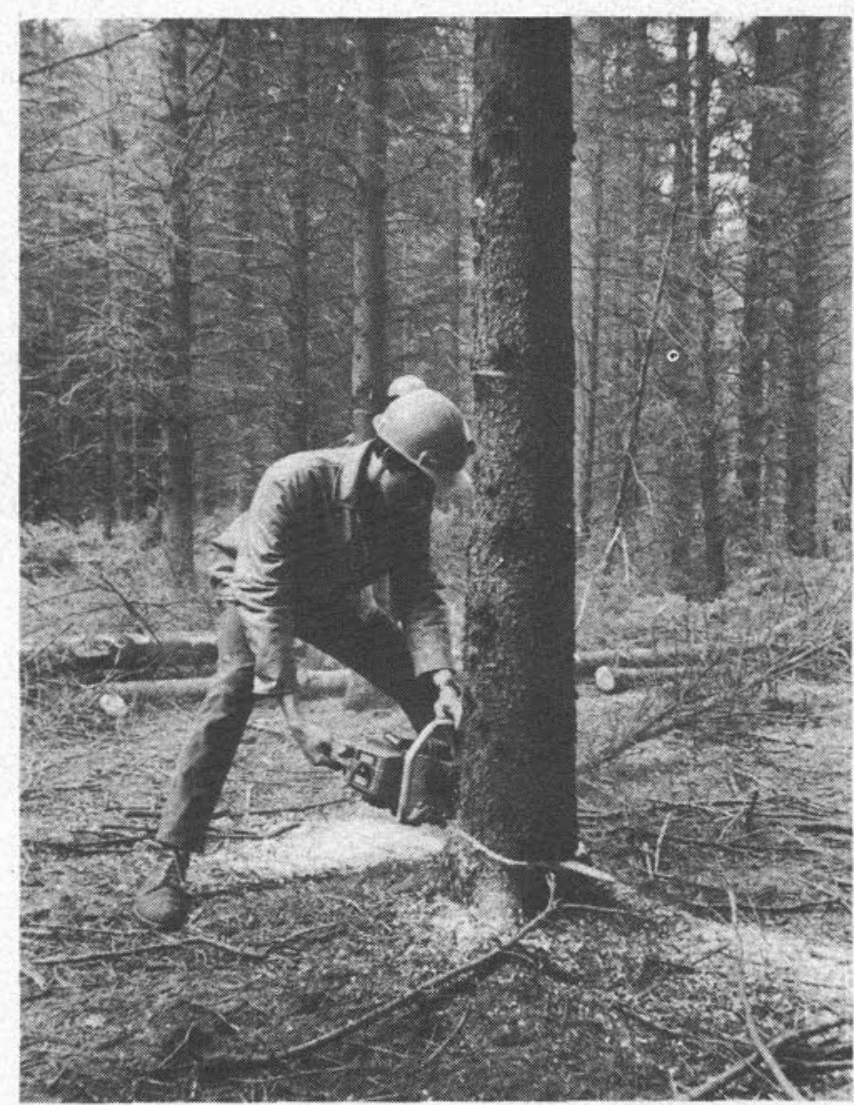

(a)

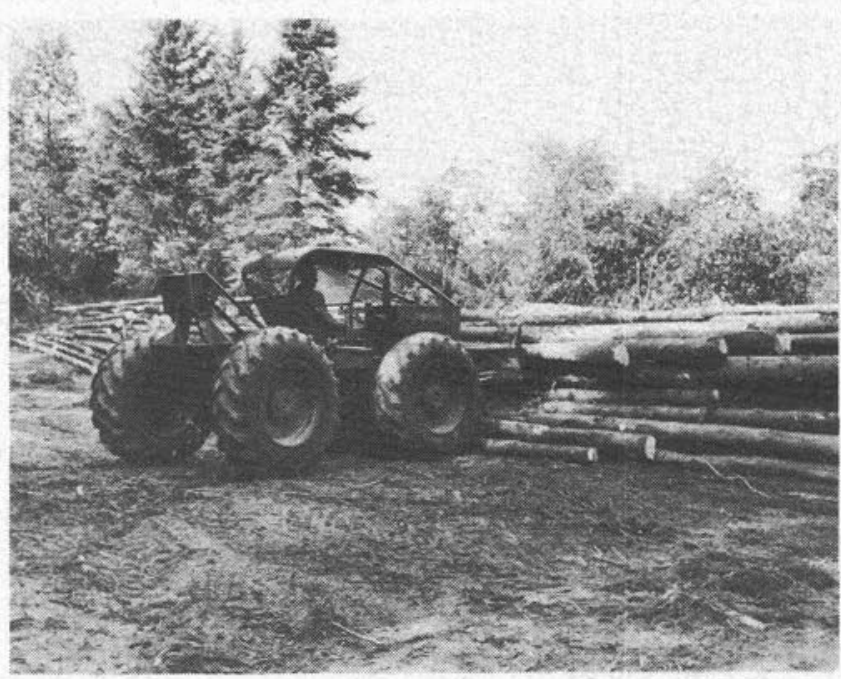

Fig. 1. (a) Felling. (b) Decking tree lengths. 


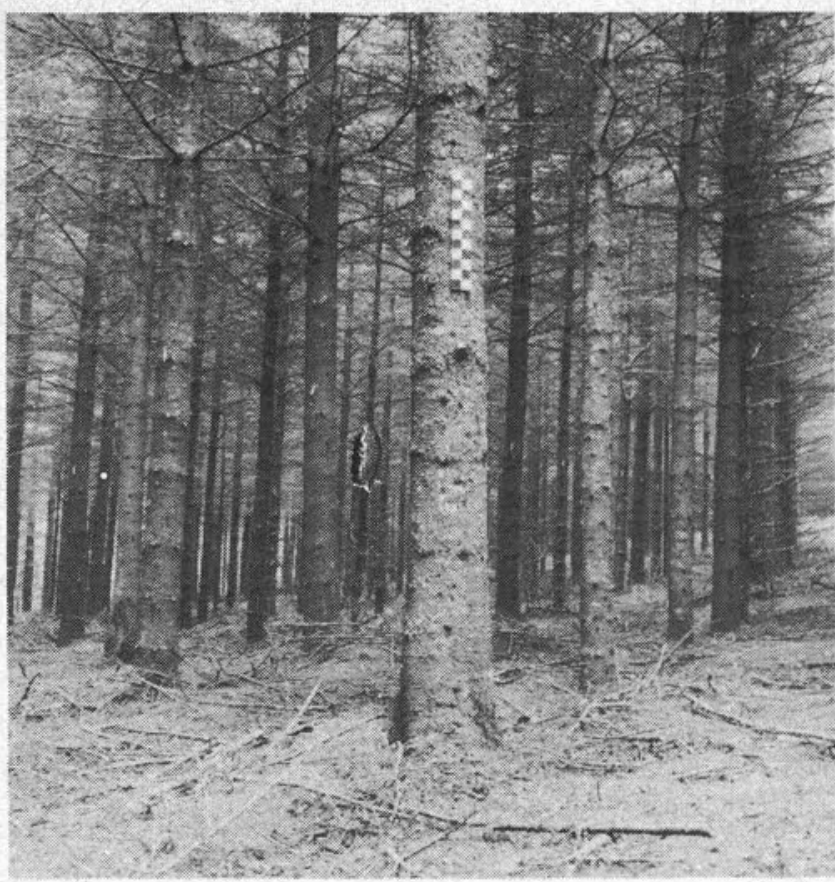

(a1958)

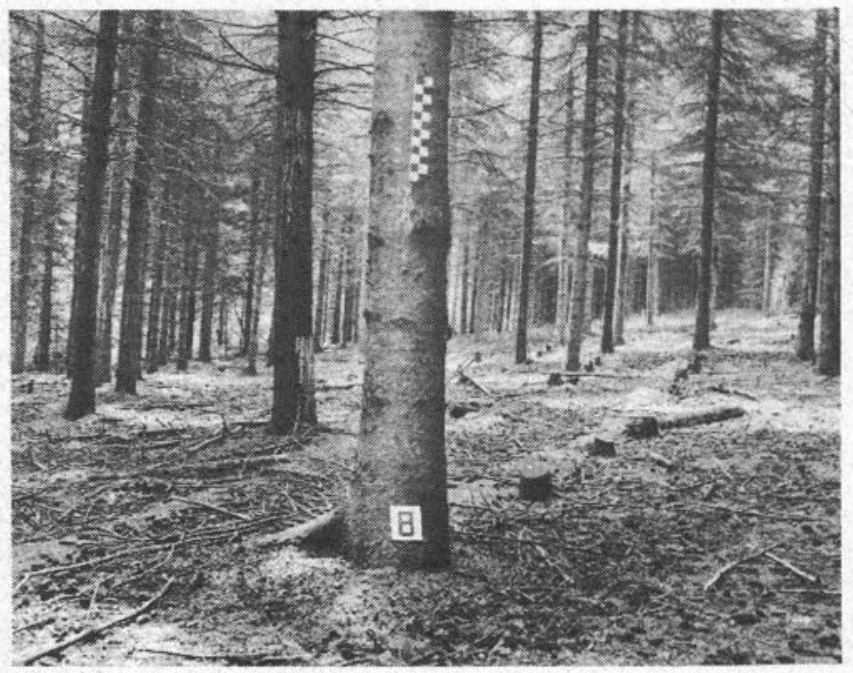

(a1968)

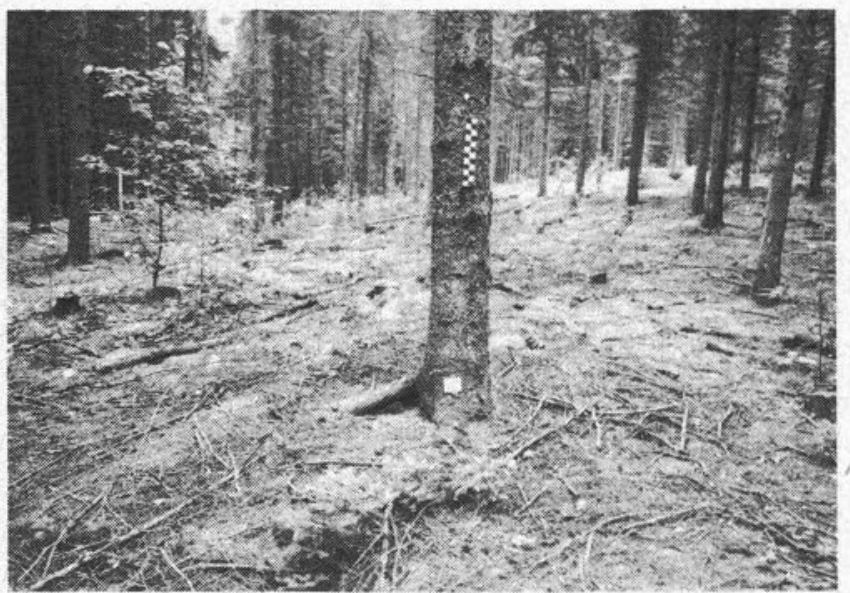

Fig. 2. Before-thinning stand conditions.

(a) Residual basal area $18 \mathrm{~m}^{2} / \mathrm{ha}$ -

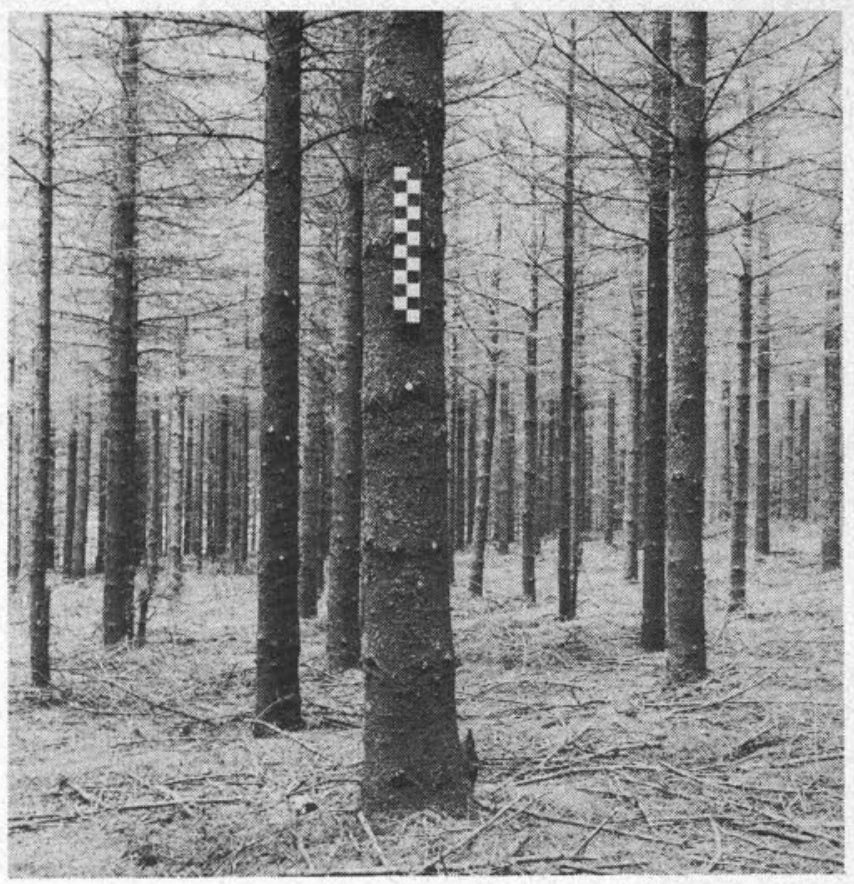

(b1958)

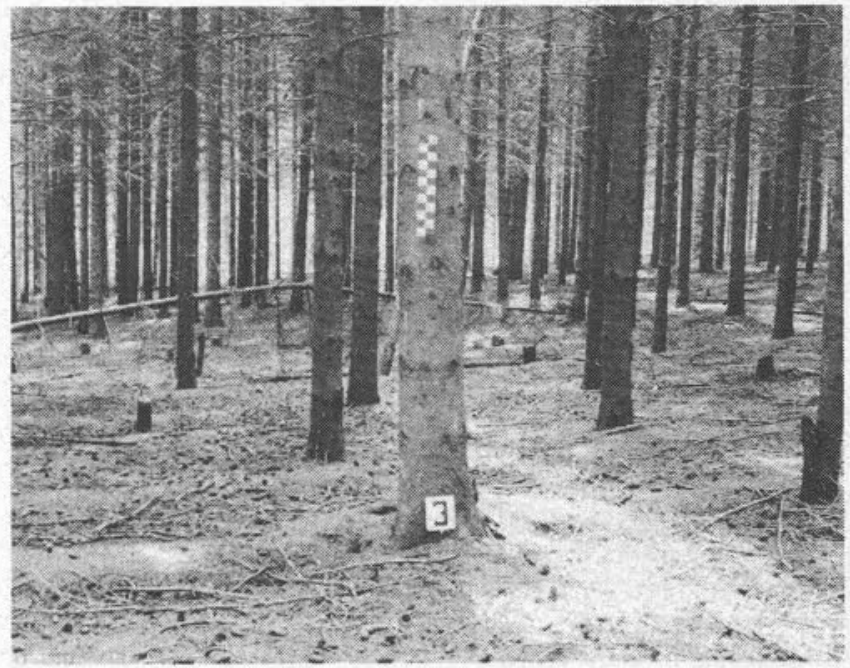

(b1968)

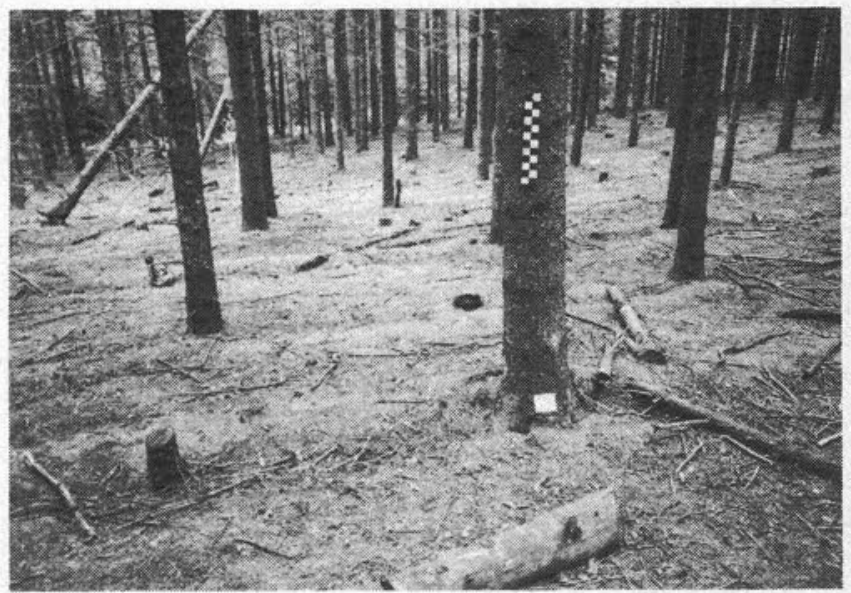

Fig. 2. (b) Residual basal area $32 \mathrm{~m}^{2} / \mathrm{ha}-$ 1958, 1968, 1978. 
fluenced similarly to mean dbh, although the differences between treatments were less pronounced.

Mean form quotient, almost identical for all treatments in 1958, was greater in 1978 but associated directly with intensity of thinning. The thinning operation itself had no immediate effect on mean form quotient in the way it had on $\mathrm{dbh}$ and height.

Basal area levels after thinning were very close to those prescribed in all cases. Control values appeared to be nearing a maximum in 1978. Total and merchantable volumes also were greatest on the control plots where they were still increasing. The magnitude of all per hectare values in 1978 was inversely related to degree of thinning.

\section{Growth and Yield}

\section{Stem Values}

Effects of stand density on stem changes are best judged by behaviour of individual trees or size classes, rather than by consideration of mean stand values which are affected artificially by the thinning itself, as noted above.

Dbh growth by $2-\mathrm{cm}$ classes shows three distinct trends (Fig. 3). (1) Larger trees grew more, but the correlations were weak and there was very high variability within classes - e.g. coefficients of variation for one plot ranged from $18 \%$ to $110 \%$. (2) Growth for a given diameter class was greater at lower residual basal areas. In this respect the controls and $32 \mathrm{~m}^{2} / \mathrm{ha}$ treatment showed little difference, and in the second period the largest trees made similar growth at all but the lowest basal area level. (3) Growth for a given $\mathrm{dbh}$ and treatment was less in the second period than in the first.

Height growth of 160 of the larger trees/ha present on each plot in 1958 and still surviving in 1978 showed some reduction in the second period, but 20 -year growth was virtually the same for all treatments (about 6.1m).

\section{Mortality}

Periodic mortality in numbers of trees is shown in Table 4.

\begin{tabular}{|c|c|c|c|c|c|}
\hline \multirow{2}{*}{\multicolumn{2}{|c|}{ Date }} & \multicolumn{4}{|c|}{ Treatment - residual basal area/ha } \\
\hline & & $18.4 \mathrm{~m}^{2}$ & $25.3 \mathrm{~m}^{2}$ & $32.1 \mathrm{~m}^{2}$ & Control \\
\hline \multicolumn{6}{|c|}{ Diameter breast height, } \\
\hline \multirow[t]{8}{*}{$\mathrm{cm}$} & $1958 \mathrm{BT}$ & 11.4 & 11.7 & 11.9 & 11.7 \\
\hline & & 14.2 & 13.7 & 13.2 & 11.7 \\
\hline & 1968 BT & 17.5 & 16.7 & 15.2 & 14.0 \\
\hline & $\mathrm{T}$ & 16.8 & 14.2 & 12.4 & - \\
\hline & AT & & & & 14.0 \\
\hline & 1978 BT & 21.6 & 20.6 & 18.5 & 16.8 \\
\hline & $\mathrm{T}$ & 18.8 & 17.3 & 15.2 & - \\
\hline & AT & 22.9 & 21.6 & 19.3 & 16.8 \\
\hline \multirow[t]{8}{*}{ Height, $m$} & 1958 BT & 9.6 & 10.2 & 10.5 & 9.7 \\
\hline & & 11.2 & 11.1 & 11.2 & 9.7 \\
\hline & 1968 BT & 14.0 & 14.3 & 14.2 & 12.9 \\
\hline & $T$ & 13.5 & 13.1 & 12.4 & - \\
\hline & AT & 14.3 & 15.1 & 14.8 & 12.9 \\
\hline & 1978 BT & 16.9 & 17.7 & 17.3 & 16.4 \\
\hline & $T$ & 15.6 & 15.9 & 15.5 & - \\
\hline & AT & 17.5 & 18.1 & 17.6 & 16.4 \\
\hline \multicolumn{6}{|c|}{ Form quotient, $\%$} \\
\hline & 1958 BT & 66.0 & 66.1 & 66.2 & 66.0 \\
\hline & AT & 66.3 & 66.1 & 66.3 & 66.0 \\
\hline & 1968 BT & 67.2 & 67.3 & 66.2 & 66.0 \\
\hline & AT & 67.0 & 67.4 & 66.4 & 66.0 \\
\hline & 1978 BT & 69.4 & 68.9 & 68.2 & 67.2 \\
\hline & AT & 69.0 & 69.2 & 68.4 & 67.2 \\
\hline
\end{tabular}

(BT — before thinning: T - thinned; AT - after thinning.)
Rates increased with time and with higher stand density, but amounts were only appreciable for the controls (Table 2). Most casualties were in the lower diameter classes, indicating mutual suppression as the principal cause. Budworm attack probably made a minor contribution and perhaps root rot as well. Blowdown was not a feature, on even the heavily cut plots.

\section{Basal Area, Volume and Foliage}

Basal area increment was lower in the second period, particularly in the controls where it had almost ceased (Fig. 4).

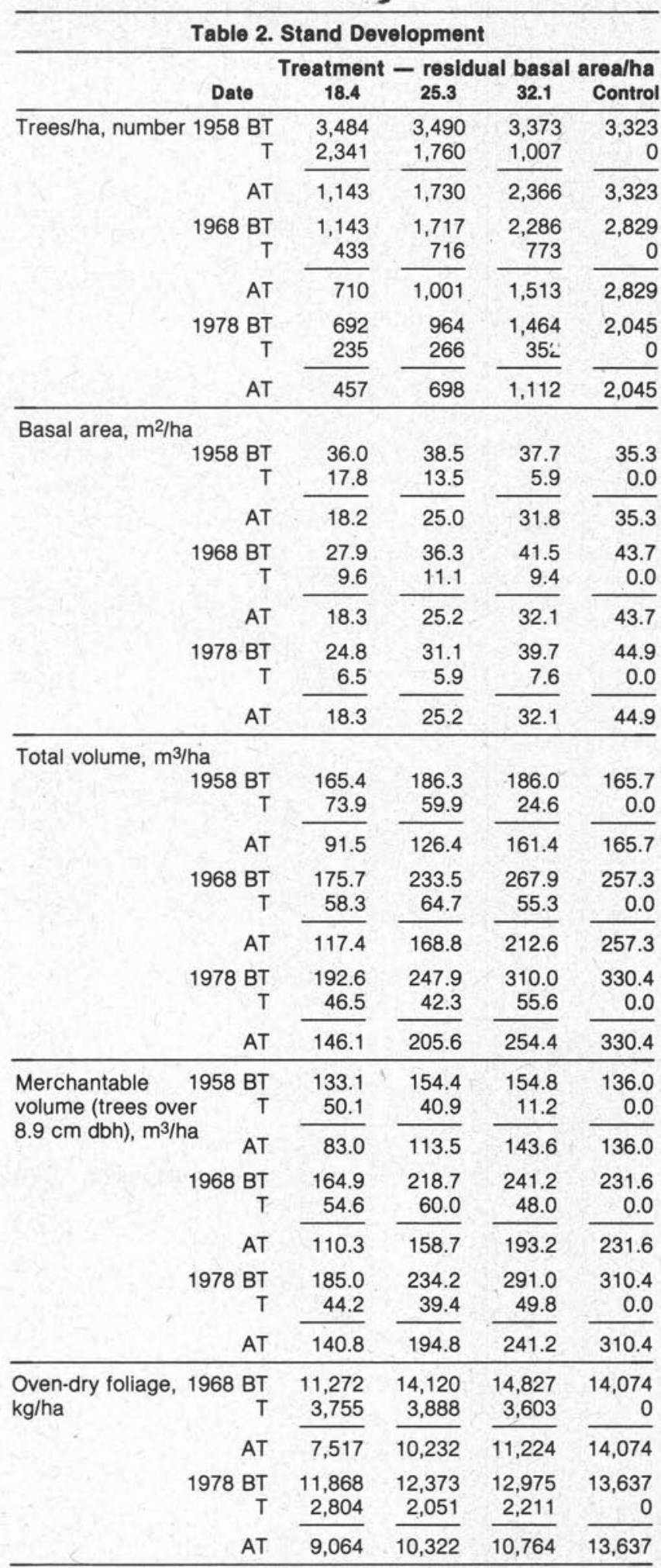



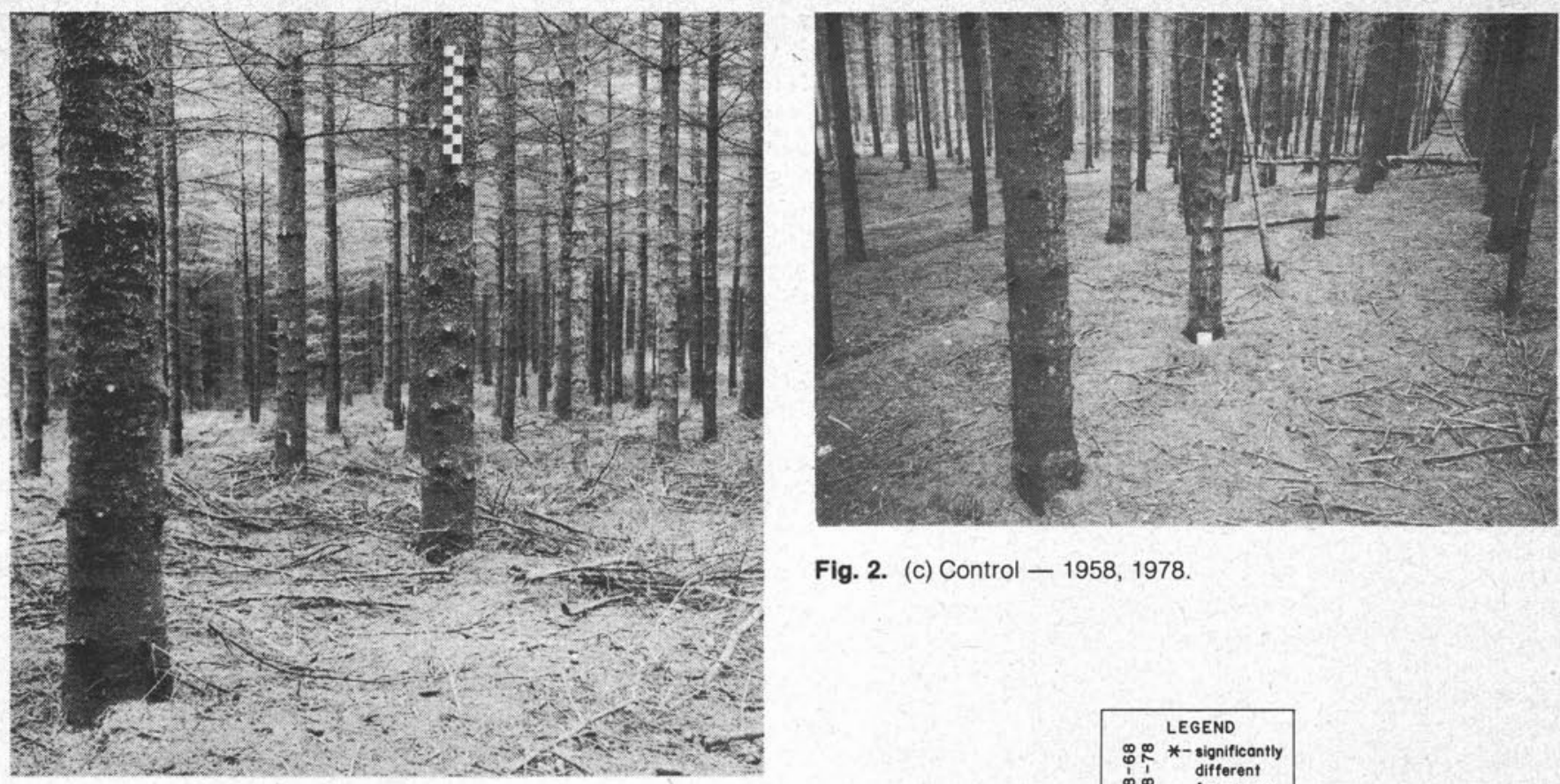

Fig. 2. (c) Control - 1958, 1978.

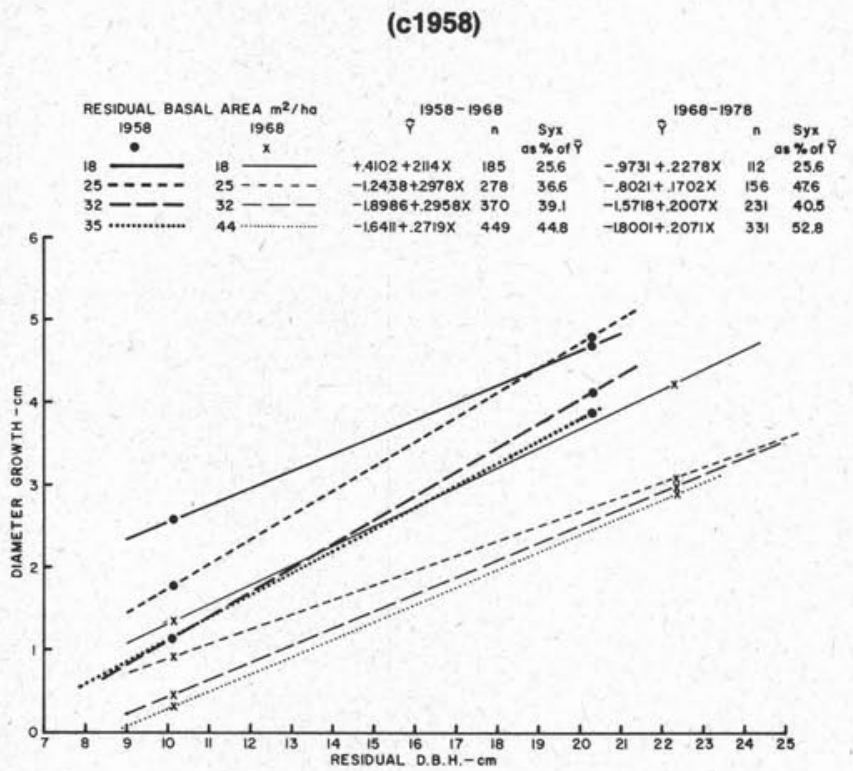

Fig. 3. Ten-year diameter growth after first two thinnings, by residual dbh classes.

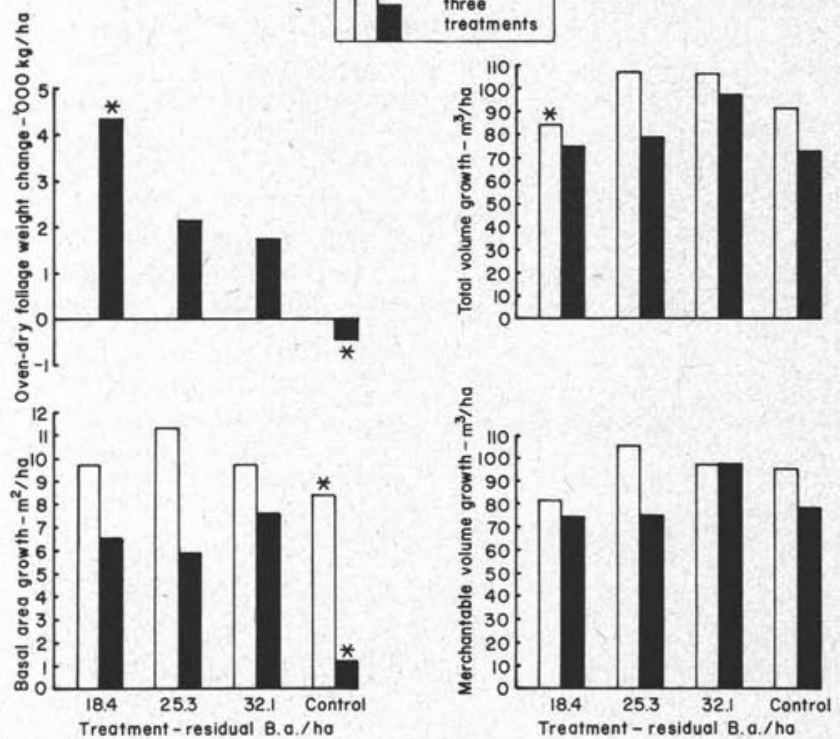

Fig. 4. Net periodic increment, by treatment.

Table 3. Diameter Distributions, Per Cent

\begin{tabular}{|c|c|c|c|c|c|c|c|c|c|c|c|c|c|c|c|c|c|}
\hline Year & $\begin{array}{c}\text { Residual } \\
\text { Basal Area } \\
\text { Class } \\
\text { (m²/ha) }\end{array}$ & 2 & 4 & 6 & 8 & 10 & 12 & $\mathrm{~cm}_{14}$ & $\begin{array}{c}\text { h cla } \\
16\end{array}$ & $\begin{array}{r}\text { ses } \\
18\end{array}$ & 20 & 22 & 24 & 26 & 28 & 30 & Total \\
\hline 1958 BT & $\begin{array}{c}18.4 \\
25.3 \\
32.1 \\
\text { Control }\end{array}$ & * & $\begin{array}{l}1 \\
2 \\
1 \\
3\end{array}$ & $\begin{array}{l}8 \\
8 \\
6 \\
9\end{array}$ & $\begin{array}{l}20 \\
15 \\
16 \\
15\end{array}$ & $\begin{array}{l}22 \\
22 \\
23 \\
21\end{array}$ & $\begin{array}{l}22 \\
21 \\
22 \\
21\end{array}$ & $\begin{array}{l}15 \\
18 \\
17 \\
16\end{array}$ & $\begin{array}{r}8 \\
9 \\
10 \\
10\end{array}$ & $\begin{array}{l}3 \\
3 \\
4 \\
3\end{array}$ & $\begin{array}{l}\star \\
2 \\
1 \\
1\end{array}$ & * & $\underline{-}$ & $\bar{z}$ & $\begin{array}{l}- \\
-\end{array}$ & & $\begin{array}{l}100 \\
100 \\
100 \\
100\end{array}$ \\
\hline 1968 BT & $\begin{array}{c}18.4 \\
25.3 \\
32.1 \\
\text { Control }\end{array}$ & & $\overline{\bar{E}}$ & $\frac{-}{2}$ & $\frac{-}{*}$ & $\begin{array}{r}- \\
7 \\
12 \\
14\end{array}$ & $\begin{array}{r}4 \\
16 \\
19 \\
21\end{array}$ & $\begin{array}{l}16 \\
19 \\
26 \\
18\end{array}$ & $\begin{array}{l}27 \\
20 \\
15 \\
16\end{array}$ & $\begin{array}{l}25 \\
19 \\
16 \\
10\end{array}$ & $\begin{array}{r}17 \\
9 \\
8 \\
5\end{array}$ & $\begin{array}{l}8 \\
8 \\
3 \\
3\end{array}$ & $\begin{array}{l}3 \\
1 \\
* \\
*\end{array}$ & $\begin{array}{l}- \\
- \\
-\end{array}$ & & & $\begin{array}{l}100 \\
100 \\
100 \\
100\end{array}$ \\
\hline $1978 \mathrm{BT}$ & $\begin{array}{c}18.4 \\
25.3 \\
32.1 \\
\text { Control }\end{array}$ & & & & $\frac{-}{\overline{1}}$ & $\begin{array}{l}- \\
\frac{2}{6}\end{array}$ & $\begin{array}{r}- \\
2 \\
1 \\
12\end{array}$ & $\begin{array}{r}4 \\
8 \\
16 \\
21\end{array}$ & $\begin{array}{l}11 \\
13 \\
17 \\
19\end{array}$ & $\begin{array}{l}19 \\
19 \\
19 \\
17\end{array}$ & $\begin{array}{l}18 \\
20 \\
23 \\
10\end{array}$ & $\begin{array}{r}15 \\
17 \\
14 \\
7\end{array}$ & $\begin{array}{r}17 \\
9 \\
6 \\
4\end{array}$ & $\begin{array}{r}11 \\
7 \\
1 \\
2\end{array}$ & $\begin{array}{l}3 \\
4 \\
1 \\
1\end{array}$ & $\begin{array}{r}2 \\
1 \\
- \\
-\end{array}$ & $\begin{array}{l}100 \\
100 \\
100 \\
100\end{array}$ \\
\hline & $*=<0.6 \%$ & & & & & & & & & & & & & & & & \\
\hline
\end{tabular}


Volume growth was also lower 1968-78. These per hectare values showed a significant convex quadratic trend with the maximum at the middle treatment levels. Increment in merchantable volume exceeded that for total volume on the controls owing to ingrowth by small diameters.

Increases in foliage weight $1968-78$ showed a significant linear trend from the lowest residual basal area down to the controls which actually made a net loss.

\section{Thinnings}

In reducing basal area to the same level as in 1958, the 1968 thinning produced higher merchantable volumes. In 1978 the cut was less than in 1958, except at treatment level $32.1 \mathrm{~m}^{2} / \mathrm{ha}$. These changes reflect the net effects of fewer trees cut at each successive operation, increasing height and therefore merchantable stem length and delayed ingrowth into merchantable diameters by small trees of the denser stand. Total thinnings from the three cuts produced $148.9,140.3$ and $109.0 \mathrm{~m}^{3} /$ ha for the residual levels of 18.4 , 25.3 and $32.1 \mathrm{~m}^{2} /$ ha respectively.

\section{Discussion}

This experiment deals with treating plantations at about the earliest age when thinning might be considered for merchantable material. The study was designed primarly to examine growth response, and because of the small areas treated costs and returns for the logging operations cannot be judged. However it is clear that selective marking causes definite problems in the initial cut at such close spacings, notably in felling without the trees lodging, and skidding without damage to the residual stand. Removal of whole rows for a plantation of this height-density combination appears the logical approach, for the first thinning at least. In this connection it should be noted that selective thinning in a plantation spaced at $2.1 \times 2.1 \mathrm{~m}$, but of the same height, did not present the difficulties just described ${ }^{3}$.

Total production, by treatment, over the life of the stand to 1978 , except for pre-1958 mortality which was minimal, is shown in Table 5 and can be summed up as follows:

(1) The heaviest thinning resulted in considerably less production than the other three treatments.

(2) The next two treatments differed mainly in volumes removed and in 1978 standing volumes.

(3) The control showed much the greatest mortality. In 1978 , m.a.i. seemed to be approaching a maximum on the control plots and clear cutting for fibre products would have been a reasonable option at that date. Had the option to clear cut in 1978 been exercised, instead of further thinning, the merchantable wood realized from standing volumes plus cuts on the 25.3 and $32.1 \mathrm{~m}^{2} /$ ha stands would have been $8.0 \%$ and $12.8 \%$, respectively, more than the $310.4 \mathrm{~m}^{3} / \mathrm{ha}$ available on the controls.

Unlike fibre production, the treated stands in 1978 showed a trend towards fewer but larger trees (and greater sawlog potential) with decreasing residual density. If clear cutting of these stands had been contemplated, shrubs and established tree seedlings of miscellaneous species would have proved an obstacle to regeneration with white spruce on the most heavily thinned area. Within 10 years the next treatment level would be similarly encumbered.

${ }^{3}$ Stiell, W. M. 1967. Clear cutting and replanting plantation areas at half-rotation ages Petawawa Forest Experiment Station Internal Rep. PS-7. 16 p.

\begin{tabular}{|c|c|c|c|c|c|c|c|c|c|c|c|c|c|}
\hline \multirow{2}{*}{$\begin{array}{c}\text { Residual Basal Area } \\
\text { Class (m²ha) }\end{array}$} & \multicolumn{11}{|c|}{$\begin{array}{c}1958 \cdot 68 \\
1958 \text { Residual } 2 \cdot \mathrm{cm} \text { dbh classes }\end{array}$} & & \multirow{2}{*}{$\begin{array}{l}\text { Stand } \\
\text { Avg }\end{array}$} \\
\hline & 2 & 4 & 6 & 8 & 10 & 12 & 14 & 16 & 18 & 20 & 22 & & \\
\hline $\begin{array}{c}18.4 \\
25.3 \\
32.1 \\
\text { Control }\end{array}$ & $\frac{\overline{-}}{\bar{E}}$ & $\frac{-}{\bar{z}}$ & $\begin{array}{l}\overline{-} \\
20.0 \\
63.8\end{array}$ & $\begin{array}{r}0.0 \\
1.3 \\
19.5 \\
31.4\end{array}$ & $\begin{array}{r}0.0 \\
1.3 \\
10.3 \\
5.8\end{array}$ & $\begin{array}{l}0.0 \\
0.3 \\
2.6 \\
2.3\end{array}$ & $\begin{array}{l}0.0 \\
0.6 \\
0.3 \\
1.4\end{array}$ & $\begin{array}{l}0.0 \\
0.9 \\
0.0 \\
1.8\end{array}$ & $\begin{array}{l}0.0 \\
0.0 \\
0.0 \\
3.3\end{array}$ & $\begin{array}{l}0.0 \\
0.0 \\
0.0 \\
0.2\end{array}$ & $\begin{array}{l}0.0 \\
0.0 \\
0.0 \\
0.0\end{array}$ & & $\begin{array}{r}0.0 \\
0.8 \\
3.4 \\
14.9 \\
\end{array}$ \\
\hline \multirow{2}{*}{$\begin{array}{c}\text { Residual Basal Area } \\
\text { Class ( } \mathrm{m}^{2} / \mathrm{ha} \text { ) }\end{array}$} & \multicolumn{12}{|c|}{$\begin{array}{c}1968-78 \\
1968 \text { Residual } 2 \cdot \mathrm{cm} \text { dbh classes }\end{array}$} & Stand \\
\hline & 4 & 6 & 8 & 10 & 12 & 14 & 16 & 18 & 20 & 22 & 24 & 26 & Avg \\
\hline $\begin{array}{c}18.4 \\
25.3 \\
32.1 \\
\text { Control }\end{array}$ & $\frac{\bar{z}}{\overline{100.0}}$ & $\frac{-}{\overline{-}}$ & $\begin{array}{r}\overline{-} \\
0.0 \\
15.8 \\
87.6\end{array}$ & $\begin{array}{r}\overline{0} \\
0.0 \\
15.8 \\
50.6\end{array}$ & $\begin{array}{r}0.0 \\
0.0 \\
8.8 \\
28.9\end{array}$ & $\begin{array}{r}1.7 \\
3.4 \\
5.4 \\
14.4\end{array}$ & $\begin{array}{l}3.9 \\
6.3 \\
2.7 \\
5.2\end{array}$ & $\begin{array}{l}6.2 \\
6.7 \\
0.0 \\
0.0\end{array}$ & $\begin{array}{l}0.3 \\
0.3 \\
0.0 \\
0.0\end{array}$ & $\begin{array}{l}0.0 \\
0.0 \\
0.0 \\
0.0\end{array}$ & $\begin{array}{l}0.0 \\
0.0 \\
0.0 \\
0.0\end{array}$ & $\begin{array}{l}0.0 \\
0.0 \\
0.0 \\
-\end{array}$ & $\begin{array}{r}2.5 \\
3.7 \\
3.2 \\
27.7\end{array}$ \\
\hline
\end{tabular}

Table 5. Total Production ( $\mathrm{m}^{3 / \mathrm{ha}}$ )

\begin{tabular}{|c|c|c|c|c|c|c|c|c|}
\hline & \multicolumn{4}{|c|}{$\begin{array}{c}\text { Total Volume } \\
\text { Residual b.a./ha }\end{array}$} & \multicolumn{4}{|c|}{$\begin{array}{l}\text { Merchantable Volume } \\
\text { Residual b.a./ha }\end{array}$} \\
\hline & 18.4 & 25.3 & 32.1 & Control & 18.4 & 25.3 & 32.1 & Control \\
\hline $\begin{array}{l}\text { Thinnings, } 1958+1968 \\
\text { Mortality, } 1958-1978 \\
\text { Volume, } 1978 \mathrm{BT}\end{array}$ & $\begin{array}{r}132.2 \\
2.6 \\
192.6\end{array}$ & $\begin{array}{r}124.6 \\
5.8 \\
247.9\end{array}$ & $\begin{array}{r}79.9 \\
5.3 \\
310.0\end{array}$ & $\begin{array}{r}0.0 \\
37.7 \\
330.5\end{array}$ & $\begin{array}{r}104.7 \\
2.4 \\
185.0\end{array}$ & $\begin{array}{r}100.9 \\
5.4 \\
234.2\end{array}$ & $\begin{array}{r}59.2 \\
4.2 \\
291.0\end{array}$ & $\begin{array}{r}0.0 \\
24.5 \\
310.4\end{array}$ \\
\hline Total Production & *327.4 & 378.3 & 395.2 & 368.1 & 292.1 & 340.5 & 354.4 & 334.9 \\
\hline
\end{tabular}

(*Significantly different). 


\section{Conclusions}

(1) Aabasal area of only $18.4 \mathrm{~m}^{2} /$ ha productivity of the type of plantation described is evidently impaired, presumably by reduction in the quantity of foliage.

(2) Thinning to leave a basal area in the range of about 22 to $35 \mathrm{~m}^{2} / \mathrm{ha}$ should yield 11 to $60 \mathrm{~m}^{3} / \mathrm{ha}$ of merchantable wood, depending on plantation age and intensity of cut, without reducing stand growth.

(3) Untreated plantations are close to their maximum m.a.i. for fibre production at 55 years, but if cut then will have lost ca. $10 \%$ of total volume through natural mortality.

(4) Invasion by tree seedlings and other woody plants increases with available light and therefore intensity of cut, and could cause serious competition to spruce regeneration within 20 years at low residual stand densities.

\section{Acknowledgments}

Thanks are due Mr. D. J. McGuire for conducting and supervising field work, compilation and drafting; Mr. D. A. MacLeod for statistical analysis of growth variables; and Mrs. M. I. Moore for identification of ground cover specimens.

\section{References}

Anon. 1948. Form-class volume tables. Can. Dep. Mines Resour., Mines, For., Sci. Serv. Branch, Dom. For. Serv., Ottawa. 2nd ed. Ottawa. 2nd ed.

Berry, A.B. 1978. Metric yield tables based on site class and spacing for white spruce plantations at the Petawawa Forest Experiment Station. Dep. Fish. Environ., Can. For. Serv., Chalk River, Ont. Inf. Rep. PS-X-70.

Freese, Frank. 1967. Elementary statistical methods for foresters. U.S. Dep. Agric., For. Serv., Washington, D. C. Agric. Handb. 317.

Stiell, W. M. 1970. Thinning 35-year-old white spruce plantations from below: 10-year results. Dep. Fish. For., Can. For. Serv., Ottawa, Ont. Publ. 1258.

\section{Considérez sous un jour réaliste votre régime d'assurance-vie IFC}

Avez-vous jamais pensé à ce que le produit de votre assurance-vie IFC assurerait à votre famille, compte tenu du coût élevé de la vie aujourd'hui? Si vous n'étiez protégé que par le montant minimum, soit $\$ 10,000$, il est certain que votre famille n'irait pas loin.

Les membres IFC et leur famille peuvent être assurés pour $\$ 100,000$ (jusqu'à l'âge de 50 ans) à des taux de primes raisonnables. Si vous n'avez pas fait une demande d'assurance pour un montant plus élevé, il serait peut-être bon que vous songiez à reconsidérer de façon plus réaliste votre régime d'assurance-vie IFC.

L'Institut Forestier du Canada a tous les détails qu'il faut. Son adresse est B.P. 5000, Collège Macdonald (Québec) H9X 1C0. 